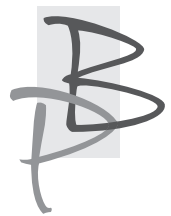

\title{
Ojczyzna według Zbigniewa Herberta
}

Streszczenie: Poezja Zbigniewa Herberta ma powinnościowy i aksjologiczny charakter - skłaniający ku określonym wartościom. Poeta opowiada się za budowaniem wartości, za wytrwałym szukaniem sensu. Również dyskurs o ojczyźnie wpisuje się w poszukiwanie i budowanie sensu. To niewątpliwie ważny motyw w twórczości autora Struny światła. Niniejszy artykuł pokazuje Herbertowską ojczyznę jako: „krwawiącą ranę”, dominantę Raportu z oblężonego Miasta, ojczyznę niezłomnych, ojczyznę w duchu filozofii Henryka Elzenberga. W poetyckim mówieniu o ojczyźnie Herbert jest bliski paradygmatowi romantycznemu.

Słowa-klucze: Zbigniew Herbert, poezja, motyw ojczyzny, aksjologia, Henryk Elzenberg.

\section{Homeland according to Zbigniew Herbert}

Summary: Zbigniew Herbert's poetry has an axiological character - inclining towards certain values. The poet is in favor of building values. Also,

Jerzy Sikora - dr hab., prof. UKSW; poeta, krytyk literacki, profesor nadzwyczajny w Katedrze Literatury XX Wieku Uniwersytetu Kardynała Stefana Wyszyńskiego w Warszawie. Członek Stowarzyszenia Pisarzy Polskich, autor dziewięciu książek poetyckich, książki prozatorskiej Pęknięte lustro. Mate prozy oraz kilku monografii naukowych, m.in. Twórczość kaznodziejska ks. Józefa Tischnera (2012). 
discourse about homeland is part of the search for meaning. This is an important motif in Herbert's work. This article presents Herbert's homeland as „bleeding wound", the dominant of Report from the besieged City, the homeland of the unbreakable, the homeland in the spirit of Elzenberg's philosophy. In poetic talk about the homeland Herbert is close to the romantic paradigm.

Key words: Zbigniew Herbert, poetry, motif of the homeland, axiology, Henryk Elzenberg.

Hans Georg Gadamer mówi, że sztuka jest przejawem aktywności ducha. Z tym łączy się między innymi jakaś doza bezinteresowności. Ale powiedzmy szczerze, nieraz artysta chce również odbiorcę, w sposób jawny lub ukryty, skłonić ku czemuś, namówić ${ }^{1}$ Taki namawiający, powinnościowy i aksjologiczny charakter - skłaniający ku określonym wartościom - ma poezja Zbigniewa Herberta. Ten poeta opowiada się za budowaniem wartości, za wytrwałym szukaniem sensu. Również dyskurs o ojczyźnie wpisuje się w poszukiwanie i budowanie sensu. To niewątpliwie ważny motyw w twórczości autora Struny światta.

\section{Ojczyna jako krwawiąca rana}

Andrzej Bursa w 1957 roku w Modlitwie dziękczynnej z wymówka pisze:

Nie uczyniłeś mnie ślepym

Dzięki Ci za to Panie

Nie uczyniłeś mnie garbatym

Dzięki Ci za to Panie

Nie uczyniłeś mnie dziecięciem alkoholika

Dzięki Ci za to Panie

1 H.G. Gadamer, Aktualność piękna. Sztuka jako gra, symbol i święto, przeł. K. Krzemieniowa, Warszawa 1993, s. 12. 
Nie uczyniłeś mnie wodogłowcem

Dzięki Ci za to Panie

Nie uczyniłeś mnie jąkałą kuternogą karłem epileptykiem

hermafrodytą koniem mchem ani niczym z fauny i flory

Dzięki Ci za to Panie

Ale dlaczego uczyniłeś mnie Polakiem?²

Adresatem podziękowań podmiotu lirycznego - porte parole autora w wierszu, tej osobliwej modlitwie, jest Bóg. Ostatni wers (puenta) jest sygnalizowaną tytułem, skierowaną do Stwórcy wymówką o to, że choć bohaterowi oszczędzono chorób, to jednak urodził się Polakiem.

Czegoś takiego nigdy nie napisałby Zbigniew Herbert. Jest on autorem Modlitwy Pana Cogito - podróżnika, utworu o charakterze dziękczynnym, ale pozbawionym krytyki. Zamiast puentującej wymówki padają słowa:

dziękuję Ci Panie że stworzyłeś świat piękny i różny

a jeśli jest to Twoje uwodzenie jestem uwiedziony na zawsze i bez wybaczenia 3

W owym „świecie pięknym i różnym” pojawia się ojczyzna pojęta jako rana, na którą podmiot mówiący w żaden sposób nie narzeka. Podejmuje związane z nią cierpienie jako rzecz naturalną. Tak rozumie swe patriotyczne zadanie, najważniejszą życiową powinność. Nie ulega pokusie wygody - nie ukrywa rany. Uznaje ją za swoją, opatruje, odnosi się do niej z czułością:

\author{
Pan Cogito \\ postanowił wrócić \\ na kamienne łono \\ ojczyzny \\ $[\ldots]$
}

2 A. Bursa, Utwory wierszem i proza, wybór, opracowanie i wstęp S. Stanuch, wyd. 3 poprawione, Kraków 1982, s. 282.

3 Z. Herbert, Raport z oblężonego Miasta, wyd. 3, Wrocław 1997, s. 21. 


\author{
przestał wierzyć w postęp \\ obchodzi go własna rana \\ wystawy obfitości \\ napawają go znudzeniem \\ [...] \\ więc po co wraca \\ pytają przyjaciele \\ z lepszego świata \\ mógłby tutaj pozostać \\ jakoś się urządzić \\ ranę powierzyć \\ chemicznym wywabiaczom \\ zostawić w poczekalni \\ wielkich portów lotniczych \\ [Pan Cogito - powrót $\left.{ }^{4}\right]$
}

Otwarta rana aktualizuje pamięć. Zabliźnienie mogłoby oznaczać zapomnienie. Poeta protestuje przeciwko zacieraniu, likwidowaniu pamięci, zasypywaniu jej wapnem:
wapno na domy i groby
wapno na pamięć
[...]
a na powierzchni spokój
wapno na pamięć
[Cmentarz warszawski ${ }^{5}$ ]

\footnotetext{
4 Tamże, s. 22-24.

5 Z. Herbert, Struna światta, wyd. 2, Wrocław 1994, s. $42-43$.
} 
Tadeusz Różewicz w wierszu ***oblicze ojczyzny... wyznaje:

na początku ojczyzna
jest blisko
na wyciągnięcie ręki
dopiero później rośnie
krwawi
boli6

Herbertowa ojczyzna jest podobna do powyższej: krwawiąca, bolesna, wymagająca. Taką się staje, kiedy naprawdę nas ona obchodzi. W Prologu padają jakże bolesne słowa:

\author{
Rów w którym płynie mętna rzeka \\ nazywam Wisłą. Ciężko wyznać: \\ na taką miłość nas skazali \\ taką przebodli nas ojczyzną ${ }^{7}$
}

Ojczyzna zostaje pokazana w pewnym odniesieniu do nas samych. Widać tu konotacje biblijne - ewangeliczne oraz powiązania z Psalmem 22, gdzie mowa jest o męce Mesjasza. Ale Herbert nie ukazuje ojczyzny jako Mesjasza narodów, lecz opisuje nas samych, którzy zostaliśmy przebici, zranieni ojczyzną. Ona jest tym raniącym nas ościeniem.

\title{
Ojczyzna w Raporcie z oblężonego Miasta
}

W tomie Raport z oblężonego Miasta, w wierszu Proces bohater mówi: „oddycham płytko bo naprawdę nie wiem, / ile minut powietrza jeszcze mi zostało"8. Herbert pisał Raport po ogłoszeniu stanu wojennego w Polsce, a więc w atmosferze niepokoju, braku swobodnego oddechu. Sytuacja podmiotu

7 Z. Herbert, Napis, wyd. 2, Wrocław 1996, s. 9.

8 Tenże, Raport z oblężonego Miasta, dz. cyt., s. 80. 
lirycznego w powyższym cytacie korespondowała z sytuacją samego autora. Gdy to pisał, był coraz bardziej chory, oddychał z coraz większym trudem.

Raport z oblężonego Miasta to Herbertowskie przesłanie zza barykady, tajna wiadomość nadana alfabetem Morse'a, wystukiwana poza czasem, dochodząca spod pozostałych po Mieście ruin. To nie jest polityczna deklaracja - gdyby chodziło tylko o nią, mielibyśmy do czynienia raczej z publicystyką niż ze sztuką, i prędko byśmy o niej zapomnieli, jak o gazecie, w którą zawija się rybę. [...] W świecie, gdzie nasze wiadomości i życie publiczne zniżyły się niemal do poziomu plotki, wieść, jaką niesie ze sobą Raport..., dotyczy tego, co wieczne. Ten wiersz to dla Herberta więcej niż aluzyjny wykład jego ars poetica; to w istocie jego ars vitae ${ }^{9}$.

Od tytułu Raport z oblężonego Miasta wziął nazwę cały zbiór wierszy, w którym w konfiguracji przestrzennej uwyraźniony jest wschód jako kierunek, skąd do ojczyzny nadciąga niebezpieczeństwo:

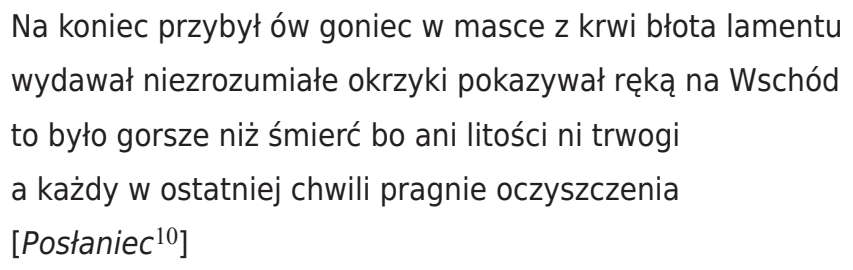

Nie sposób nie wspomnieć o enigmatycznie, ale jakże aluzyjnie zatytułowanym wierszu 17 IX: „Moja bezbronna ojczyzna przyjmie cię najeźdźco / a droga którą Jaś i Małgosia dreptali do szkoły / nie rozstąpi się w przepaść" ${ }^{11}$. Wiersz zadedykowano Józefowi Czapskiemu, który dobrze znał sowieckiego najeźdźcę, uczestniczył on bowiem jako delegat rządu RP na emigracji w międzynarodowej komisji badającej zbrodnię katyńską. Przeżycia z pobytu

9 C.L. Haven, Zbigniew Herbert: „,Nadzieja matka gtupich”. Raport z oblężonego Miasta czytany w Kalifornii, przeł. K. Korsyk, [w:] Świat piękny i bardzo różny. Szkice o wojażach Pana Cogito, red. J.M. Ruszar i D. Siwor, Kraków 2018, s. 130.

10 Z. Herbert, Raport z oblężonego Miasta, dz. cyt., s. 24.

11 Tamże, s. 85. 
w sowieckich obozach opisał w książkach: Wspomnienia starobielskie i $N a$ nieludzkiej ziemi.

W Raporcie z oblężonego Miasta ojczyzna jest nieszczęśliwa, samotna, ale się nie poddaje. Czym są „nasza odmowa niezgoda i upór”, o tym mówi wyraźnie wiersz Potęga smaku:

\author{
To wcale nie wymagało wielkiego charakteru \\ nasza odmowa niezgoda i upór \\ mieliśmy odrobinę koniecznej odwagi \\ lecz w gruncie rzeczy była to sprawa smaku \\ Tak smaku \\ w którym są włókna duszy i chrząstki sumienia ${ }^{12}$
}

Osamotnienie w nieszczęściu nie oznacza rezygnacji, obrona będzie trwała do końca i taki opór „pomimo wszystko” wcale nie jest bezsensowny:

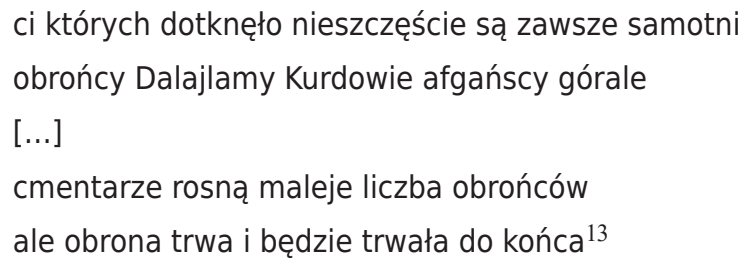

Na początku lat dziewięćdziesiątych Herbert odwiedził Izrael. Celem tej podróży było zdobycie Masady ${ }^{14}$. Bardzo dobrze wpisuje się to w aksjologię powołanych przez niego do życia bohaterów i sytuacji ich moralnych wyborów. Bo czymże jest Masada? ${ }^{15}$ Symbolem heroicznej walki, odwagi, wier-

12 Tamże, s. 92.

13 Tamże, s. 102.

14 „Główny cel został osiągnięty: zdobyłem pieszo MASADĘ, trzy dni przed wyjazdem, podejściem pieszo, Ścieżką Węża, bez śniadania (w hotelu zapomniano mnie zbudzić - ach, hotele Jerozolimy, nie mogę was wspominać dobrze), bez wody, w złych butach, a przecież zrobiłem tę drogę w niecałe trzy kwadranse. Więc opłacił się cały trud". Z. Herbert, D. Weinfeld, Listy, oprac. R. Krynicki, Kraków 2009, s. 23.

15 Masada to starożytna twierdza żydowska na szczycie płaskowyżu na wschodnim 
ności wyznawanym ideałom rycerskiego etosu i szlachetnego patriotyzmu. Symbolem mężnego oporu aż do końca. W tym kontekście można przywołać słowa z Raportu z oblężonego Miasta: ,i jeśli Miasto padnie a ocaleje jeden / on będzie niósł Miasto w sobie po drogach wygnania / on będzie Miasto" ${ }^{16}$. Na ruinach Masady izraelscy żołnierze składają przysięgę wojskową, wypowiadając słowa: „Masada nigdy więcej nie zostanie zdobyta” ${ }^{17}$.

Ojczyźniane myślenie Herberta ma charakter powinnościowy: jestem Polakiem, więc przynależę do ojczyzny, której na imię Polska. Z tym wiążą się określone zachowania, a przede wszystkim zobowiązania. Poeta nie szafuje słowem „Polska”. Ba! W jego wszystkich wierszach nie pojawia się ono ani razu. Nie ma go nawet w pisanym w stanie wojennym przejmującym Raporcie z oblężonego Miasta. Właśnie „oblężone Miasto” jest znakiem Polski, wymownym symbolem polskiego losu.

\section{Ojczyzna niezlomnych}

W poezji Herberta pojawiają się bohaterowie różni, jednak nie znajdziemy wśród nich uciekinierów. O Panu Cogito poeta powie: „nigdy / nie pociągała go rola / bohatera ucieczki" (Gra Pana Cogito ${ }^{18}$ ). Niezłomność, trwanie na posterunku aż do końca - to cechuje bohaterów Herberta.

Tego poetę dobrze znała Stefania Kossowska - czołowa postać niezłomnej londyńskiej emigracji ${ }^{19}$. Kossowską z Herbertem łączyło miejsce urodzenia - Lwów. Łączyła ich też niezłomność, bezkompromisowość, etyczność. Pamiętam, jak w rozmowie ze mną latem 1992 roku w Londynie mówiła z przejęciem o wierszu Album Orwella, który to utwór w rękopisie Herbert przesłał

skraju Pustyni Judejskiej nad Morzem Martwym. Według relacji Józefa Flawiusza w 77 roku była jednym z ostatnich punktów oporu żydowskich powstańców przeciw Rzymianom. Kiedy powstańcy wobec wielokrotnie przeważających sił wroga dostrzegli bezcelowość obrony, zbiorowo popełnili samobójstwo.

16 Z. Herbert, Raport z oblężonego Miasta, dz. cyt., s. 102.

17 https://pl.wikipedia.org/wiki/Masada [dostęp: 11.03.2018].

18 Z. Herbert, Pan Cogito, wyd. 2, Wrocław 1993, s. 81 [pierwsze wydanie w 1992].

19 Stefania Kossowska (1909-2003) - publicystka i pisarka, redaktorka naczelna londyńskich „Wiadomości” (1973-1981). Współpracowała z Radiem Wolna Europa, podpisała list pisarzy polskich na Obczyźnie solidaryzujących się z sygnatariuszami protestu przeciwko zmianom w Konstytucji Polskiej Rzeczpospolitej Ludowej (List 59). 
jej z paryskiego szpitala. Miała mały udział w ostatecznym jego brzmieniu. Chodziło o obecny w nim motyw „białej flagi”. Już nie pamiętam, o co dokładnie chodziło, ale w listowej rozmowie o tym wierszu prawdopodobnie Herbert posłuchał delikatnej sugestii pani Stefanii. Oto ten dyskutowany fragment:

\author{
Na szczęście nie ma jego fotografii \\ ze szpitala. Łóżko. Biała flaga ręcznika \\ przy krwawiących ustach. On jednak nigdy się nie podda 20
}

Wiersz wszedł w skład tomu Rovigo z 1992 roku. Kossowska otrzymała tę książkę od Herberta z następującą dedykacją: „Drogiej Pani Stefanii Kossowskiej wszystkie nadwiślańskie kwiaty - i wdzięczność za to - że zechciała stworzyć - nad moją skołataną głową - kolorową, letnią parasolkę swojej Dobroci”21. Fraza „Wszystkie nadwiślańskie kwiaty” u kogoś innego mogłaby pobrzmiewać nazbyt patetycznie, wręcz sztucznie - ale nie u Herberta. U niego takie słowa oznaczały żywy symbol i namiastkę ojczyzny. Przesyłał on je osobie będącej z dala od rodzinnego kraju, solidaryzował się z jej emigracyjnym losem. Akceptował jej niezłomność i bezkompromisowość.

Kazimierz Wierzyński w 1942 roku w Nowym Jorku pisał w wierszu Ktokolwiek jesteś bez ojczyzny:
Bo nie ma ziemi wybieranej,
Jest tylko ziemia przeznaczona,
Ze wszystkich bogactw - cztery ściany,
Z całego świata - tamta strona ${ }^{22}$.

I Wierzyński, i Herbert opowiadają się za konkretną ojczyzną - „ziemią przeznaczoną”, „tamtą stroną”. Oczywiście, przez takie widzenie nie wyrzekają się „większej” ojczyzny mieszczącej się w ramach - tak jak ich własna -

20 Tenże, Rovigo, wyd. 2, Wrocław 1997, s. 9.

21 J. Sikora, Wino, kruche ciasteczka i śnięte ryby. O Stefanii Kossowskiej, „Wiadomości Literackie" 2013, nr 4, s. 6-9.

22 K. Wierzyński, Wybór poezji, wybór, opracowanie i wstęp K. Dybciak, Wrocław-Warszawa-Kraków 1991, s. 217. 
kulturowej tradycji: atlantyckiej, śródziemnomorskiej. „Wybór polskości staje się wyborem przede wszystkim moralnym. Jest więc patriotyzm Herberta patriotyzmem, który można by określić jako wyprany z nacjonalizmu"23. Jako otwarty na innych, na inne narody, dające ubogacenie chociażby naszej kulturze ${ }^{24}$.

Już prawie umierający, w łóżku, podłączony do butli z tlenem ułatwiającej oddychanie, Herbert recytuje - a raczej z trudem wykrztusza z siebie - własne wiersze, jak również swoich ulubionych poetów. Jakich? Juliusza Słowackiego (Sowiński w okopach Woli), Cypriana Kamila Norwida (Bema pamięci żatobny rapsod) i Tadeusza Gajcego (Przed snem). Można to zaliczyć do przedostatnich, jakby testamentowych czynności poety. 8 maja 1998 roku w mieszkaniu Herberta przy ulicy Promenady Radio Kraków aranżuje wyjazdowe studio nagrań, aby uwiecznić ostatni publiczny głos autora Pana Cogito. „Niespełna trzy miesiące później, 29 lipca nad ranem, Zbigniew Herbert odszedł między Wysokie Cienie"25. Własne wiersze czytał, a ulubionych poetów mówił z pamięci. Znał je bardzo dobrze, towarzyszyły mu na jego drodze życia, i przywołał je teraz, gdy ta droga dobiegała kresu. Wpisują się one w nurt patriotyczny, niepodległościowy, bohaterski. Oto jenerał Sowiński - „Polak prawy" - w utworze Słowackiego, waleczny Bem u Norwida czy tyrtejska, prorocza nuta w wierszu Gajcego z refrenem: „Nie zatrzymamy się” - w domyśle: aż zwyciężymy. Jesteśmy niezłomni. s. 146 .

24 „Lwów wywarł szalony wpływ na mnie. Teraz dopiero to doceniam. Przede wszystkim jako miasto wielonarodowościowe. Od urodzenia niemal zaszczepiony byłem przeciwko wszelkiej ksenofobii. Antysemityzm jest dla mnie czymś niezrozumiałym. Ja się bawiłem z Żydami, to byli moi najlepsi koledzy: z piaskownicy, z boiska, ze szkoły. Okrucieństwo uświadomienia sobie różnic narodowych przyszło potem. Nie chciałbym idealizować, oczywiście dochodziło do różnych konfliktów i tarć w mieście, gdzie nawet niecała połowa to byli Polacy, reszta to Austriacy, Żydzi, Ukraińcy, Rosjanie, Bułgarzy - specjaliści od pomidorów, Ormianie - od stuleci zajmujący się handlem, Włosi, Grecy. [...] Ogromnym bogactwem każdej kultury jest wielonarodowość. Dla mnie Polska bez mniejszości, zwłaszcza bez ruchliwej, inteligentnej, żywej mniejszości żydowskiej, jest czymś zubożałym”. Humanistyka to przygoda. Ze Zbigniewem Herbertem rozmawia Monika Muskała, pierwodruk „Notatnik Teatralny” 1996, nr 11. Za: Herbert nieznany. Rozmowy, zebrał i oprac. H. Citko, Warszawa 2008, s. 209.

25 T. Burek, W te dni przedostatnie [tekst dołączony do płyty CD Zbigniew Herbert czyta swoje wiersze], Radio Kraków 1998. 
Jakże ważna jest dla Herberta międzyludzka solidarność i wzorce osób niezłomnych: babcia Maria z Bałabanów, prof. Stroński (Pan od przyrody), Henryk Elzenberg, rabi Nachman czy Gilgamesz, Hektor, Roland ${ }^{26}$. Poeta odwołuje się do etosu rycerskiego. Nie gloryfikuje swojej ojczyzny, widzi jej słabości, niedostatki, to nie patriotyzm triumfalny, ale ofiarny, gorzki. Herbertowej ojczyźnie towarzyszy zwykle obraz trudnego losu, gorycz przegranej, a nawet klęski. W odniesieniu do ojczyzny poeta postępuje - i zaleca postępować - według kodeksu właśnie rycerskiego, a więc heroicznego, na śmierć i życie, bez żadnych kalkulacji. Nie jest to kodeks prywatny ani kodeks Dekalogu ${ }^{27}$. W nim szczególnie liczy się odwaga, wierność, współczucie, pamięć. Najwyraźniej poeta daje temu wyraz w Przestaniu Pana Cogito. Ale nie tylko. Dla mnie jednym z najpiękniejszych wierszy Herberta o odwadze jest Tarnina:

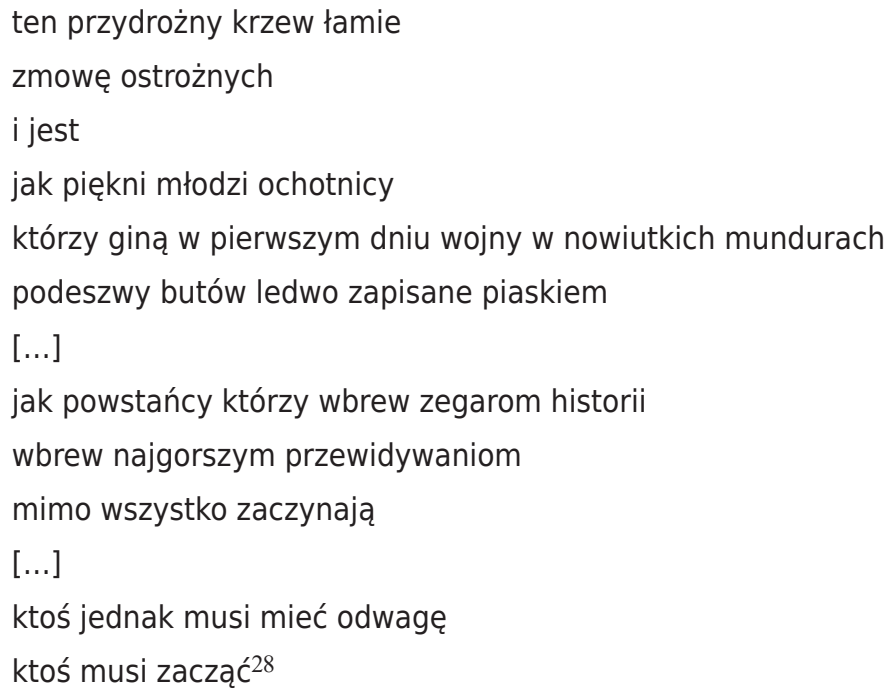

\section{Ojczyna Herberta w duchu Elzenberga}

O narodzie i ojczyźnie oraz o wzajemnych relacjach między nimi tak pisał Henryk Elzenberg:

26 „Moralną rację mają postacie znajdujące się bliżej ubóstwa niż bogactwa, pokory niż pewności, braku niż pełni, cierpienia niż zadowolenia”. K. - s. 179.

27 Z. Najder, dz. cyt., s. 148-149.

28 Z. Herbert, Elegia na odejście, wyd. 2, Wrocław 1997, s. 12-13. 
Kochać cały naród to nonsens; można - bez zaślepienia - kochać jedynie pewne jego, zwykle skromne, zalety i co lepszych jego przedstawicieli. Ale z narodem jest związana i zespolona ojczyzna, a z tą jest inaczej. Ojczyzna to twór idealny, coś wyciągniętego z niebytu wysiłkiem najlepszych w narodzie, coś co unosi się ponad ludźmi, [...] ognisko, w którym się skupiają tęsknoty, porywy i aspiracje. Wyobcować z narodu jest względnie łatwo; ale nikt nie może na serio chcieć człowieka pozbawić ojczyzny ${ }^{29}$.

Herbert jako uczeń Elzenberga, wyznający system wartości swojego mistrza, idealizował ojczyznę. ,[...] kochał Polskę idealną, może wyidealizowaną. A widział naszą małość. Najbardziej kiedy wróciliśmy do Polski w latach dziewięćdziesiątych"30 - wspomina żona poety. Było to niedługo po transformacji ustrojowej, po PRL-u, po odzyskaniu wolności. Jednak przemiana systemu i odzyskiwanie wolności to pewien proces, to czas trudny, a nawet w jakimś sensie tragiczny. Tak też określał wolność w okresie międzywojennym Kazimierz Wierzyński tytułem tomu wierszy Wolność tragiczna, który ukazał się w 1936 roku, a więc osiemnaście lat po odzyskaniu przez Polskę niepodległości. Takie przemyślenia miał poeta w rok po śmierci Józefa Piłsudskiego. Wielkość Marszałka kontrastuje z resztą, która nie potrafi docenić i odpowiednio zagospodarować wolności. Tytułowa „wolność tragiczna” pojawia się w wierszu o wymownym tytule: Ojczyzna chochołów ${ }^{31}$. Podobne jest spojrzenie Herberta na Polskę lat dziewięćdziesiątych, chociaż to już jest inna Polska niż za komunizmu. O tamtych latach komunistycznego zniewolenia poeta w wierszu Do Henryka Elzenberga w stulecie urodzin powie: „Żyliśmy w czasach które zaiste były opowieścią idioty / Pełną hałasu i zbrodni”32.

Ale wróćmy do początków III RP. Otóż Herbert zawiódł się co do niejednego ze swoich wcześniejszych przyjaciół, chociażby do Adama Michnika. Nie mógł zaakceptować, jak redaktor naczelny „Gazety Wyborczej” może bronić generała Jaruzelskiego. Na łamach „Tygodnika Solidarność” mówił

29 H. Elzenberg, Kłopot z istnieniem. Aforyzmy w porzadku czasu, Kraków 1994, s. 264.

30 K. Herbertowa, Ze Zbigniewem Herbertem mój życiorys, [w:] Wierność. Wspomnienia o Zbigniewie Herbercie, oprac. A. Romaniuk, Warszawa 2014, s. 157.

31 K. Wierzyński, dz. cyt., s. 147.

32 Z. Herbert, Rovigo, dz. cyt., s. 5. 
o Michniku: „Przestałem rozumieć meandry jego myślenia, wierzyłem w jego intelekt, a także w zwykłą uczciwość - zawiodłem się. [...] Jest on klasycznym przykładem kariery komunistycznego Dyzmy"33.

Zdaniem Herberta, naturą poezji jest (powinno być) uniwersalne współczucie. „To jest właśnie to otworzenie się na świat, otworzenie się na świat w akcie miłości, w akcie współczucia, w akcie współdziałania” ${ }^{34}$. Ale współczucie nie oznacza przebaczenia. W Przesłaniu Pana Cogito czytamy:

\author{
niech nie opuszcza ciebie twoja siostra Pogarda \\ dla szpiclów katów tchórzy [...] \\ i nie przebaczaj zaiste nie w twojej mocy \\ przebaczać w imieniu tych których zdradzono o świcie ${ }^{35}$
}

Oddajmy jeszcze głos Elzenbergowi, który tak mówił o polskiej nekropolii:

[...] cmentarz wojenny [...]. Suma życia wspólnego, ucieleśnionego w owych pomnikach i krzyżach, jest niebywała. Wszystko tu jest: ofiarność poległych, ból ich bliskich, pietyzm ogółu, tchnienie wielkiej duchowej wspólnoty, bohaterstwo i kult bohaterstwa: idzie się tymi alejami i jest się porwanym przez pęd zbiorowości ${ }^{36}$.

I znowu, patrząc na wiersze Herberta i inne formy jego wypowiedzi, znajdujemy wspólność zapatrywania z powyżej cytowanym filozofem. Inaczej jest u Miłosza, z którym Herbert co do zapatrywania na ojczyznę polemizował, a nawet się kłócił.

Jeśli dla Miłosza ojczyzną była przede wszystkim jego rodzinna okolica, nurt rzeki, na którą patrzył jako chłopiec, ludzka gromada, dwór i wieś z jego litewskopolską tożsamością, następnie zaś polski język i polska literatura, to dla Herberta ojczyzna w tym sensie, jaki pojęciu temu nadawał Elzenberg, stanowi wartość,

33 Herbert nieznany. Rozmowy, dz. cyt., s. 231.

34 Gtosy Herberta, oprac. B. Toruńczyk, Warszawa 2008, s. 184.

35 Z. Herbert, Pan Cogito, dz. cyt., s. 88-89.

36 H. Elzenberg, dz. cyt., s. 195. 
której nie da się wyminąć, wierność jej pozostaje [...] «okrwawionym węzłem», jakiego nie może rozwiązać jednostka. Podobnie jak toruński profesor, także jego uczeń wzruszał się, myśląc o żołnierskich kwaterach, brzozowych krzyżach na Powązkach, zmarli Herberta, inaczej niż zmarli Miłosza, noszą polskie mundury z różnych bitew i czasów, mundury splamione krwią i zetlałe, a ich milczące nawoływanie jest niczym głos rycerskiego rogu Rolanda, wezwanie o pomoc, którego nie można odrzucić37.

Miłosz traktował ojczyznę jakby w dwóch skrajnościach: wąsko, aspektowo albo nad wyraz pojemnie - chętnie widział siebie jako obywatela Wielkiego Księstwa Litewskiego. Znane jest wydarzenie, które między innymi przyczyniło się do poróżnienia Herberta z Miłoszem. Otóż ten pierwszy był nie tylko zniesmaczony, ale i oburzony, gdy wraz z żoną będąc na kolacji u Miłoszów w Berkley w międzynarodowym towarzystwie, usłyszał z ust gospodarza przyjęcia dowcip o Polsce jako szesnastej republice ZSRR. Autor Pana Cogito skwitował to słowami: „Ojczyzna to zbyt poważna sprawa, aby o niej opowiadać dowcipy" i wyszedł, trzaskając drzwiami.

Katarzyna Herbertowa wspomina rozmowę swojego męża z Miłoszem w drugiej połowie lat osiemdziesiątych:

Zbyszek mi mówi, choć nie pamiętam, czy dokładnie tak brzmiało to sformułowanie: „On [Miłosz] powiedział, że te polskie mundury były takie śmieszne, a ja odparłem, że przecież w tych mundurach ginęli ludzie”. Miłosz czasami mówił coś prowokacyjnego albo dowcipnego i tak charakterystycznie się śmiał. Dla Herberta pewne rzeczy były po prostu nie do śmiechu ${ }^{38}$.

Prawdopodobnie chodziło o mundury ułańskie. Herbert żart z munduru odczuwał jako naruszenie więzi ze zmarłymi. Nieraz w swojej poezji sięgał do obrazu guzików z żołnierskiego płaszcza, które pozostały po zamordowanych ${ }^{39}$. W wierszu Guziki rozlega się wołanie:

37 A. Franaszek, Herbert. Biografia, t. 2: Pan Cogito, Kraków 2018, s. 682.

38 Z Katarzyna Herbertowa rozmawiat Maciej Tabor, Warszawa, 14 grudnia 2005, [w:] Z. Herbert, Cz. Miłosz, Korespondencja, oprac. B. Toruńczyk i M. Tabor, Warszawa 2006, s. 180.

39 Zob. A. Franaszek, dz. cyt., s. 683. 
tylko guziki nieugięte

potężny głos zamilkłych chórów

tylko guziki nieugięte

guziki z płaszczy i mundurów ${ }^{40}$

To są guziki z katyńskiego grobu - wytrwałe znaki pamięci, świadkowie zbrodni, którą oprawcy chcieli puścić w niepamięć. Chrzęst guzików jako pamiątek umieszczonych w pudełku po zapałkach upomina się o przerwanie milczącego zapominania:

\author{
Praliśmy potem długie lata \\ bandaże. Teraz nikt nie płacze \\ chrzęszczą w pudełku po zapałkach \\ guziki z żołnierskiego płaszcza \\ [Prolog $\left.{ }^{41}\right]$
}

Zdaniem Herberta, „Miłosz wyrzekł się świadomie patriotyzmu w czystym jego znaczeniu, ojczyzny wreszcie, uczynił brak Tożsamości motorem swojej poezji" ${ }^{4}$. Na pewno Herbert i Miłosz ojczyznę i tożsamość pojmowali inaczej - z tym, że Miłosz swobodniej i może wygodniej, a Herbert jako brzemię:

\author{
Emigracja jako forma egzystencji rzecz ciekawa \\ bez przyjaciół i bez krewnych pod namiotem \\ żyć bez sankcji obowiązków każdy przyzna \\ że na barkach ciąży nam ojczyzna
}

$\left[\right.$ Chodasiewicz ${ }^{43}$ ]

Mówi się, że Miłosz miał problem z ojczyzną, z określeniem się: kim jestem. Litwinem? Polakiem? Obywatelem świata? Z powyższego repertuaru

40 Z. Herbert, Rovigo, dz. cyt., s. 21.

41 Tenże, Napis, dz. cyt., s. 8.

42 Tenże, O kanon języka i literatury, [w:] Z. Herbert, Cz. Miłosz, Korespondencja, oprac. B. Toruńczyk i M. Tabor, Warszawa 2006, s. 143.

43 Tenże, Rovigo, dz. cyt., s. 46. 
- w zależności od sytuacji - wybierał identyfikacje takie, które były mu potrzebne. W jakim celu? Aby pokazać jakoby swoje ojczyźniane rozdarcie? Aby prowokować innych? A może po prostu po to, aby czuć się dobrze.

Natomiast Herbert miał naprawdę kłopot z ojczyzną. Była ona mu krwawiącą raną, „cierpkim obolem pod językiem”44. Dlaczego? Dlatego że traktował ją śmiertelnie poważnie, a czasem aż idealistycznie. Dramat Herberta z ojczyzną wynikał z dużego rozdźwięku między ojczyzną - Polską - w rzeczywistości a ojczyzną w sferze pragnień, oczekiwań. Henryk Elzenberg miał „kłopot $\mathrm{z}$ istnieniem". Jego pojętny uczeń też miał ów egzystencjalny kłopot, a w jego obrębie kłopot $\mathrm{z}$ ojczyzną. $\mathrm{W}$ gruncie rzeczy jest to problem ontologiczny i tożsamościowy, gdyż ewokuje jakże ważne i trudne pytanie: kim jestem?

„Po co mówić o granicach i pograniczach $\mathrm{w}$ dobie znoszenia granic i unitaryzacji? W dobie równych obywateli, równych przepisów i jabłek produkowanych na miarę biurokratycznie skonstruowanego typu idealnego?" - pyta Izabela Drozdowska na łamach „Borussii”. I odpowiada: „Może dlatego, że są miejsca, gdzie jabłka smakują inaczej, choć nie rosną w idyllicznym sadzie"45. Takim miejscem, właśnie nie idyllicznym sadem, ale jednak ważnym i bliskim sercu jest dla Herberta ojczyzna. Bohater Powrotu prokonsula mógłby pozostać „w odległej prowincji”, a jednak wraca „na dwór cesarza”, do ojczyzny, gdzie władcy można - i trzeba - wiele zarzucić. I mówi, dlaczego wraca:
nie mogę żyć wśród winnic wszystko tu nie moje drzewa są bez korzeni domy bez fundamentów deszcz szklany kwiaty pachną woskiem o puste niebo kołacze suchy obłok ${ }^{46}$

I Herbert, i Miłosz wiele podróżowali. Dla nich obu ojczyzna była istotnym punktem odniesienia, chociaż innym. Wynikało to także z tego, że Miłosz miał status emigranta. Dla Herberta Polska była miejscem częstszych powrotów. On swoje europejskie peregrynacje odbywa po wcześniejszych odwiedzinach

44 Nike, która się waha, [w:] Z. Herbert, Struna światta, dz. cyt., s. 74.

45 I. Dąbrowska, O fotografiach, których nie zrobiono. Nowe oblicze pograniczy, „Borussia” 2006, nr 37, s. 135.

46 Z. Herbert, Studium przedmiotu, wyd. 2 poprawione, Wrocław 1997, s. 41. 
i poznawaniu różnych zakątków własnej ojczyzny. Na przykład na przełomie lat 50. i 60. ubiegłego wieku często odwiedza Suwalszczyznę i pozostaje pod jej urokiem ${ }^{47}$.

$*$

Raz po raz odżywają dyskusje, czy Herbert jest bardziej klasykiem, czy jednak romantykiem? A poeta - jego twórczość - skutecznie wymyka się wyraźnym dystynkcjom i zaszufladkowaniom. Na ogół dzieje się tak, gdy mamy do czynienia z twórczością wybitną. Jednak gdybyśmy jeszcze raz spróbowali usytuować autora Raportu z oblężonego Miasta jako podejmującego motyw ojczyzny względem powyżej wspomnianych paradygmatów, to bliższy jest on wzorcowi romantycznemu - poprzez widzenie ojczyzny jako rany, poprzez szacunek dla przodków, docenienie ofiarności i bohaterstwa.

\section{Bibliografia}

Dybciak K., Ocalanie wartości. Epistemologia i aksjologia w dziele Zbigniewa Herberta, [w:] tenże, Trudne spotkanie. Literatura polska XX wieku wobec religii, Kraków 2005.

Elzenberg H., Kłopot z istnieniem. Aforyzmy w porządku czasu, Kraków 1994. Haven C. L., Zbigniew Herbert: „Nadzieja matką głupich”. Raport z oblężonego Miasta czytany w Kalifornii, przeł. K. Korsyk, [w:] Świat piękny i bardzo różny. Szkice o wojażach Pana Cogito, red. J.M. Ruszar i D. Siwor, Kraków 2018.

Herbert nieznany. Rozmowy, zebrał i oprac. H. Citko, Warszawa 2008.

Herbert Z., Elegia na odejście, wyd. 2, Wrocław 1997.

Herbert Z., Napis, wyd. 2, Wrocław 1996.

Herbert Z., Pan Cogito, wyd. 2, Wrocław 1993.

Herbert Z., Raport z oblężonego Miasta, wyd. 3, Wrocław 1997.

Herbert Z., Rovigo, wyd. 2, Wrocław 1997.

47 Z. Fałtynowicz, Podróże bliskie. Zbigniew Herbert i Suwalszczyzna, Suwałki 2008. 
Herbert Z., Studium przedmiotu, wyd. 2 poprawione, Wrocław 1997.

Herbert Z., Struna światła, wyd. 2, Wrocław 1994.

Herbert Z., Miłosz C., Korespondencja, oprac. B. Toruńczyk i M. Tabor, Warszawa 2006.

Herbert Z., Weinfeld D., Listy, oprac. R. Krynicki, Kraków 2009.

Herbertowa K., Ze Zbigniewem Herbertem mój życiorys, [w:] Wierność. Wspomnienia o Zbigniewie Herbercie, oprac. A. Romaniuk, Warszawa 2014.

Franaszek A., Herbert. Biografia, t. 2: Pan Cogito, Kraków 2018.

Najder Z., Ojczyzna i naród w poezji Zbigniewa Herberta, „Ethos” 2000, nr 52.

Sikora J., Wino, kruche ciasteczka i śnięte ryby. O Stefanii Kossowskiej, „Wiadomości Literackie" 2013, nr 4.

Wierzyński K., Wybór poezji, wybór, opracowanie i wstęp K. Dybciak, Wrocław-Warszawa-Kraków 1991. 